\title{
Research on Reform of University Public English Teaching Management based on Network Background
}

\author{
Huimin Sun ${ }^{1, a}$ \\ ${ }^{1}$ Foreign Languages' College, Beihua University, Jilin 132013, China. \\ ahuimin_sun@126.com
}

Keywords: reform, university English teaching, network background.

\begin{abstract}
Web-based university English teaching has got advantages of multimedia integration and cross-platform sharing of resources with the application and popularization of internet Technology. This completely new teaching model university English teaching is proposed to a broader space for development by meeting the need of university students, promoting their personalized learning, improving their independent learning ability, and renewing teaching concept as well. At the same time, some reforms are put forward while a certain achievements. Many thinking's concerned are given in light of teacher training, teaching and management model, evaluation method, teaching concept, etc., which aims at bettering university English teaching.
\end{abstract}

\section{Introduction}

The demand of the times, the organic integration of modern network technology and college English teaching has become an inevitable trend. In the teaching and management of public English, change the traditional teaching mode, make full use of modern information technology, adjust the classroom teaching structure of public English reasonably, find out a scientific and feasible evaluation scheme or system, stimulate students to learn English subjectively And improve the efficiency of college English teaching and improve the quality of college English education, which is the purpose of this study.

At present, college English teaching is facing the challenge of modern educational technology. How to improve the teaching quality of public English is the subject that English teachers and educators must solve. In February 2004, the "College English Teaching Requirements" promulgated by the Higher Education Department of the Ministry of Education clearly pointed out that "colleges and universities should make full use of network technology and adopt a new teaching mode to improve the original single classroom teaching mode, The new teaching mode should be supported by modern information technology, especially network technology, so that the teaching of public English in universities is not restricted by time, place, class and so on, and develop towards individualized learning and autonomous learning. The integration of contemporary advanced network technology and college English teaching methods is an important condition and foundation of English curriculum integration. China's traditional college English classroom teaching model is the teacher lectures, students passive lectures, this single teaching model limits the development of student personality. Under the environment of network, college English teaching can provide more contact and use of language for students 'foreign language learning. It is more conducive to cultivating and developing students' ability of autonomous learning and practical application of English.

At present, many colleges and universities in China's cities and regions have recognized the need for network technology and university public English teaching integration, have set up multimedia classrooms, network classrooms, etc., at the same time in the campus network to open a network teaching platform, Fully taking into account the teachers use the network preparation and teaching needs for teachers equipped with computers, laser pens and so on. With the rapid development of China's economy, the process of educational information is changing with each passing day. In the field of higher education, the role and status of modern network information technology in college 
English teaching is becoming more and more important, and it is used by more and more universities. However, how to use modern network technology environment to promote college English teaching?

How to integrate and transcend the traditional teaching mode? This is the question that we college English educators and managers should think about and solve. Practice has proved that in college English teaching in the use of network technology-based modern information technology to design and carry out a variety of classroom teaching activities, so that the original abstract, boring, a single learning content into interesting, visual , Audible interactive content, is conducive to students in a relaxed atmosphere of learning while learning, learning and use, so that the content of classroom teaching more substantial, richer, more in line with the times, more conducive to stimulate student interest in learning and Enthusiasm, and guide them to take the initiative to carry out self-study, consciously and happily learned in the use of knowledge to be consolidated and improved. Teachers use the network technology for English teaching ability has also been greatly improved. This teaching process can not only improve the information literacy of teachers, but also improve the students' ability to use modern information technology, laying a solid foundation for their lifelong learning and future career development.

\section{The Present Situation of College English Teaching in the Network Environment}

From the results of the survey and literature search, since the reform of college English teaching, the university public English teaching under the network environment of colleges and universities in China has made certain achievements, in theory and practice for the future college English teaching mode The exploration and innovation provided the basis. Some colleges and universities which have already implemented the teaching reform and have achieved certain effect have actively studied and made use of the constructivism theory and constructed the new teaching model, Information technology teaching methods, fully and rationally using the network and multimedia-aided teaching, emphasizing the interactive teaching with students, changing the traditional English teaching tradition of the "one-man", "full house" teaching form, student-centered classroom teaching content, To reverse the role of teachers, established a "teacher-led, student-centered" teaching mode. At the same time, in the evaluation method, also changed the traditional "a test set the pros and cons" situation, innovative form of "process evaluation and the end of the evaluation of combining" a new evaluation.

Various colleges and universities attach great importance to campus cultural activities, carried out a variety of diverse forms of college English and related campus cultural activities, such as the English corner, The use of in - class and extra - curricular comprehensive optimization of the university 's public English learning environment, expanding the English learning and practice space, improve the practical application of English ability of college students.

\section{An Analysis of the Causes of the Problems in College English Teaching under the Network Environment}

In the interview, some teachers reported that some colleges and universities on the "College English Curriculum Requirements (Trial)" is not enough understanding, not to carry out and implement it seriously, and even deviate from the basic guiding ideology of college English teaching reform, the University of English Network teaching reform is simply understood as the purchase of some equipment, the construction of a network center, connecting the campus network can be completely ignored the network environment of college English teaching maintenance, integration and management of the importance and necessity. In fact, the use of multimedia network for college English teaching, the equipment and technology requirements are high. However, at present, because some colleges and universities have insufficient funds for the teaching of public English in the university, the hardware supporting equipment can not meet the needs of college English teaching. Especially since the enrollment expansion in 1999, the majority of college students are increasing year by year, The rate of English learning per person is getting lower and lower, which makes many 
students lose interest in learning English using network technology, extra-curricular use of network resources or teaching software, the efficiency of autonomous learning greatly reduced. Some of the old school equipment aging, not updated all year round, the computer configuration is low, slow speed, headphones, microphones, sound cards and other equipment are often malfunctioning, and even often crash. Some multimedia classroom projection screen can not rise or the text on the screen is not clear, there are multimedia classroom network connection is poor and so on, so that the network learning environment wasted a lot of valuable learning time for students, resulting in a lot of students And seriously hurt the students' enthusiasm and initiative to use the Internet to learn college English. This has affected students to improve the efficiency of college English learning by using network technology and hindered the realization of college English education goals. Some schools because of inadequate protection of network equipment, can not guarantee students free Internet access, virtually increasing the cost of student learning, which is part of the students to give up the use of the network for English learning reasons. Therefore, colleges and universities should strengthen the improvement of English learning environment and hardware facilities, timely updating of equipment, to ensure capital investment, effective protection of college English classroom teaching effectiveness and extra-curricular self-learning efficiency.

\section{Strategies of Improving the Teaching and Management of College English in the Network Environment}

Nowadays, the globalization of world economic information is accelerating. It is an important task for us to cultivate a large number of talents with high English application ability, especially listening and speaking ability to meet the needs of international exchange. To this end, the Ministry of Education of the College English teaching reform as "higher education teaching quality and teaching reform project" is an important part. The main task of the reform is how to make full use of advanced information technology, inherit the characteristics of traditional classroom teaching on the basis of breakthroughs in the past English learning "teachers listen to students" model, reform of college English teaching model, continue to explore and study, give full play to modern The advantages of network technology in college English teaching, to improve the enthusiasm of students to learn English, to build a platform for independent learning, personalized learning and collaborative learning, so that English learning has become an important part of campus culture construction. Through the study of English, cultivate students 'self-learning ability and study habits, improve the students' English comprehensive cultural accomplishment.

In any course system, "student-oriented" is always the core of teaching, university public English teaching is no exception. The fundamental purpose of foreign language teaching is to develop students' English language skills - listening, speaking, reading, writing, translation comprehensive ability. To achieve this goal, we must completely change the traditional teaching mode, change the "teacher as the main" to "student-centered." Only students as the main body, from a scientific point of view from the long-term development goals to develop students' language skills. For a long time, traditional English teaching is based on the teacher-centered teaching model, teachers are the protagonist of classroom teaching: teachers say, students take notes; teacher demonstration, students imitate; teacher questions, students answer; A compliance. This "full house" approach to teaching students to become a passive language knowledge of recipients, strangling the enthusiasm and creativity of students, students often only have the language knowledge, but do not have the ability to use language, learning is "dumb English" , Contrary to the purpose of learning a foreign language, that is, to develop language communication skills.

\section{Summary}

The 21st century is a century of constantly updating information. Modern information technology, especially network application technology, is inevitably integrated into all aspects of people 's life. It also permeates into the teaching of college public English and enters the public English classroom. 
As can be seen from the above five chapters, under the network environment, college English teaching is more vivid and interesting compared with the traditional teaching mode. The combination of classroom teaching and self-study after school students not only arouse students' enthusiasm, Their self-learning ability, for their self-awareness and innovation ability has played a very important role in promoting. At the same time, the college English teaching under the network environment also brings the opportunity for the improvement of college English teachers 'information literacy, which provides strong guarantee for the inspection and supervision of college English teachers' classroom teaching organization and after-school tasks. More importantly, The traditional concept of college English teachers has been changed, and the teachers' teaching ability and scientific research ability have been improved.

Modern college English education is facing a deep change, the application of modern network technology to the traditional college English teaching into the dynamic, has brought challenges, but also brought opportunities to change the college English teaching model and It is more suitable for the development of contemporary society, and embodies the "student-centered" educational philosophy, which becomes an indispensable and effective means in the process of college English teaching. We should pay more attention to the application of network technology in university public English teaching, change the idea, update the idea, explore the effective teaching mode, build a scientific and reasonable monitoring system, improve the evaluation system, conscientiously study and continuously enrich the College English learning resource library . Through continuous efforts, the advantages of network technology and college English teaching will be organically integrated to improve students' English comprehensive quality, improve the teaching level of college English teachers, and push university public English teaching in higher education to a new height.

\section{Acknowledgements:}

Education research Beihua University: "English curriculum and teaching theory" classroom teaching and online teaching and practice of combining Dynamic Model

\section{References}

[1] Li Hong Ye. Educational Principles and Information Technology: Who is the Master - Research on the Teaching Methods in the English Teaching Model Based on the Multimedia Network. Foreign Language Circles, 2004 (4)

[2] Gu Shimin.Application of Autonomous Learning Mode and Classroom Teaching Mode under Computer Network Environment.Electronic Foreign Language Teaching, 2007

[3] MAO Ming-yong Analysis of the Current Situation of College English Teachers' Online Teaching Ability (in Chinese), 2007 (2)

[4] HOU Li-qun.Study on the Relationship between College English Teaching and Students' Application Abilities Based on Internet Journal of Sichuan International Studies University, 2009, 25 (1)

[5] ZHANG Yu-Lian, XIN Yan. Practice and Reflections on College English Teaching Reform under the Network Environment Journal of Beijing Agricultural College, 2007 (6): 114-12.

[6] CAI Ji-gang. Reflections on the Reorientation of College English Teaching in China. Foreign Language Teaching and Research, 2010 (4)

[7] The Problems and Countermeasures of College English Teaching Online Education, 2009, (9).

[8] BAO Jie-Jie.Study on the Evaluation System of College English Autonomous Learning under the Network Environment.Technology and Practice, 2011 (2) 